\title{
Stereotypes Determining Perceptions of Female Politicians: The Case of Poland
}

\author{
AGNIESZKA TURSKA-KAWA AND AGATA OLSZANECKA-MARMOLA
}

\section{$\$$ sciendo}

Politics in Central Europe (ISSN: 1801-3422)

Vol. 14, No. 3

DOI: 10.2478/pce-2018-0016

\begin{abstract}
The aim of this study is to find out whether women in Polish politics are perceived through the prism of gender stereotypes. We conducted a two-stage empirical study ( $N=447)$ to investigate the kinds of qualities that young voters attribute to politicians in the context of gender stereotypes. Our findings correlated with a pattern of research that shows that female politicians are typically associated with "female issues" and seen in terms of stereotypically feminine traits. The results of our survey showed gender solidarity, with female and male participants generally responding more positively to politicians of the same gender. There were also significant differences based on respondents' interest in politics; people interested in politics were, for example, significantly less likely to ascribe qualities related to political ability and self-composure to women. Finally, ideological identifications did not modify perceptions of female politicians but people who identified as right-wing more often viewed male politicians as politically capable, diligent, likeable and go-getters.
\end{abstract}

Keywords: women in politics, gender stereotypes, female politicians, politics, Poland

\section{Introduction}

The Polish political scene is known for the low proportion of women in public office. The democratisation processes that Poland underwent in the early 1990s did not involve an increase in the number of women in positions of public authority. This was typical of all Central and Eastern European countries (Inter-Parliamentary Union 1995) where the ancien regime gave rise to a society 
dominated by patriarchal values. In this context, post-Communist societies are often referred to as conservative or "neo-conservative" when it comes to the social role of women (Siklova 1993). Marody and Giza-Poleszczuk (2000) argue that during the socialist period in Poland, the dominant image of womanhood was that of the mother; this was later transformed into a model of the "brave victim." These researchers also point out that despite systemic changes and the emergence of a new image of women as attractive, independent and professionally active, the Polish mother stereotype has in some ways been preserved in the public imagination.

After Poland's first entirely free elections in 1991, fewer than $10 \%$ of all seats in the Sejm (lower chamber) were occupied by women (Fuszara 2010: 90). Over the next two terms, the proportion of women in the lower house was around $13 \%$. The introduction of recommended representation quotas by the victorious Democratic Left Alliance-Labor United coalition (SLD-UP) and growing public calls for equal rights for women helped increase the proportion of women in the lower chamber to $20 \%$. The Polish Electoral Code, which was adopted in 2011, stipulated that at least $35 \%$ of candidates on party lists should be women. Still this measure did not bring the expected significant changes: in the 2011 elections, only $23.9 \%$ of successful candidates were women. This may have been due to the low share of women in prime positions on candidate lists, but it also reflected the fact that social values and attitudes had not yet adapted to the new conditions.

The negligible presence of women in Polish politics is also apparent from an analysis of those holding appointed positions (i.e. as ministers and party leaders). In the 1990-2015 period, women constituted only $11.3 \%$ of ministers (including members of the Council of Ministers without assigned departments) and Ewa Kopacz was the only woman to lead a relevant party. The country has had two female prime ministers (Kopacz and Hanna Suchocka), however in both these cases, this was a result of cabinet reshuffles and not elections. The 2015 election campaign saw a dramatic change in the leadership of the main political parties. For the first time in Polish electoral history, women were the leaders of the two biggest competing parties: Civic Platform was headed by Prime Minister Ewa Kopacz, who had assumed the position one year before (after Donald Tusk became president of the European Council) while Law and Justice was led by Beata Szydło. Barbara Nowacka, a woman representing the third most important political group, United Left, also competed for the chance to be head of government. One possible goal of this female leadership was to temper perceptions of the political realm as tough, devoid of empathy and combative, a view reinforced by numerous recent disputes on the political scene.

After the 2015 parliamentary elections, Polish politics saw some changes. United Left did not hold any seats, having failed to reach the threshold for parliamentary representation, a situation that naturally marginalised Barbara 
Nowacka. Ewa Kopacz did not stand for the position of chairperson of Civic Platform, and on 26 January 2016, that role was assumed by Grzegorz Schetyna. Beata Szydło became Poland's new prime minister but she was widely perceived as dependent on Law and Justice chairperson Jarosław Kaczyński. Polish politics, thus, remained the domain of domineering men. The marginalisation of women is also confirmed by recent data on the percentage of women in representative bodies. The proportion of women in the lower chamber is $27.4 \%$ while in the senate, it is $13 \%$.

\section{From social role to stereotype}

The social position of each gender is connected with role divisions. Studies by various anthropologists point to a number of conclusions: first, gender is the basis for the attribution of social tasks and the different roles attached; second, certain tasks are consistently assigned to one gender only; and third, apart from a few tasks that are assigned on the basis of biological sex, there is a great diversity in role allocation culturally: what is regarded as feminine behaviour in one community may be characteristic of men in another (Goodman 1992: 168; Marszałek 2008: 268). During the socialisation process, women are mostly taught and prepared to serve traditional roles connected with the family and the provision of care, while men are prepared to perform professional roles. Women tend to develop a calmer, friendlier, milder, conciliatory approach while men are expected to be aggressive and proactive (Mandal 1995; Vasta et al. 1995). Research shows that women are more sensitive than men around issues concerning care for the ill; they feel more responsible for the health of their family members (Verbrugge - Wingard 1987) and have greater emotional competence (Filipiak 2001). Bakan (1966) describes the social orientation of women as communal and that of men as agentic. A communal orientation emphasises emotional closeness, caring for others and reciprocity while an agentic one stresses efficiency and strength.

\section{Gender stereotypes in politics}

Traditional understandings of masculine and feminine roles generate stereotypes. A gender stereotype is an oversimplified belief or idea about the behaviour of male and female individuals that is shared by most people in a society and learnt in the course of growing up and socialisation (Deaux - Lewis 1984). Brannon (2017) notes:

[A] gender stereotype consists of beliefs about the psychological traits and characteristics of, as well as the activities appropriate to, men or women. These beliefs often have something to do with the behaviours typically performed 
by women and men in a particular culture, but gender stereotypes are more generalized beliefs and attitudes about masculinity and femininity. (p. 46)

Gender stereotypes have descriptive and prescriptive components (Bauer 2013). The descriptive part results from the fact that gender stereotypes provide a "standard of comparison in construing the implications of behavioral information" for men and women (Lambert - Wyer Jr. 1990). This is connected with the stereotypical attribution of certain personality traits to women. The prescriptive part refers to expectations about women's behaviour. According to scholars, stereotypical prescriptions for women maintain "traditional emphases on interpersonal sensitivity, niceness, modesty, and sociability" (Prentice - Carranza 2002: 275).

Children adopt gender stereotypes at a very early stage of development, either by learning them directly or by observing gender-related social roles and behaviours (Hoffmann - Hurst 1990). Later, these stereotypes are consolidated or reinforced during the process of education, in the workplace and through the media. Stereotypes reflect the different roles attributed to men and women: the masculine role is more agentic and proactive while the feminine one is more connected with community-building, empathy and milder emotions (Eagly 1987). Stereotypes are a useful cognitive tool, especially when people have limited information about particular phenomena, individuals or social groups. This is also relevant in the sphere of politics (Rahn 1993; Lau - Redlawsk 2001). According to Sambomatsu (2002), the concept of "gender stereotypes" may be more helpful than that of "voter discrimination" because gender stereotypes offer (positive and negative) information about a voter's view of candidates. An individual whose original views are based on gender stereotypes may update their "baseline preference" if they have new experiences with candidates and elected officials that alter their long-term beliefs about female candidates.

Politics is generally considered to be a "masculine" area of work. Voters prefer candidates with "masculine" qualities at each level of the electoral competition (Rosenwasser - Dean 1989). Empirical studies show that politicians tend to be described as strong, ruthless, competitive, able to manipulate others and concerned with their own interests (Jarymowicz 1976; Reykowski 2000). Women's role in politics, thus, conflicts in some ways with the traits and dispositions attributed to women. Female politicians must transcend the social and professional roles traditionally associated with women. This also affects the strategies which female candidates use when competing for political positions. These women often flout gender stereotypes, assuming qualities deemed to be masculine or emphasising their competence in areas typically associated with men.

Experiments prove that even when male and female politicians have identical messages, women are most often associated with stereotypical "female" topics 
while men are considered more knowledgeable on "male" issues (Sapiro 1982; Matland 1994). Other studies show that perceptions of women politicians are significantly better when their campaigns focus on typical "female issues" (Kahn 1996). In this respect, women do far better on social issues and men on economic ones (Kahn 1993).

According to Huddy and Terkildsen (1993), there are two types of gender stereotypes in the realm of politics: belief stereotypes, which concern the areas of men's and women's respective political activities, and trait stereotypes, which relate to the traits attributed to each gender. In the case of belief stereotypes, women are perceived as being better at handling "female" issues such as education, health care, social welfare and environmental protection while men are said to be more fluent in "male" issues like defence, crime and terrorism prevention, the economy, public finance, commerce, agriculture and foreign policy (Rosenwasser - Seale 1988; Rosenwasser - Dean 1989; Leeper 1991; Alexander Andersen 1993; Brown et al. 1993; Kahn 1996; Koch 1999; King - Matland 2003; Dolan 2004; Dolan 2010). This is confirmed by several American studies of legislative activity, which show that women lawmakers tend to focus on issues stereotypically regarded as female (Thomas 1991; Norton 1999). In addition, the ideological positions of politicians are often stereotyped based on gender. Women politicians are presumed to be more leftist than men (Dolan 2014; Devroe - Wauters 2017). As regards trait stereotypes, women who work in politics are perceived as being more empathetic, expressive, trustworthy, consensus-oriented and able to deal with constituents than men; they are also viewed as less resolute than male politicians (Burrell 1994; Kahn 1996). In contrast, men are regarded as more assertive and rational than women (Huddy - Terkildsen 1993). They are generally seen as resolute, competent, strong leaders who are able to cope with crisis situations (Paul - Smith 2008).

These stereotypes are not surprising since they simply extrapolate from private, domestic roles to the public sector (Sapiro 1983: 146). A study by Lawless (2004) showed that after 11 September 2001, women candidates faced greater voter disapproval because public fears were focused on the threat of terrorism, and men were perceived as being more effective at handling this threat.

Another view of the stereotypes about women in politics is presented by Schneider and Bos (2014). Their study found that female politicians were "a subtype of the superordinate group women"; as such, stereotypes about women in politics were more related to stereotypes about professional women than to general perceptions of the gender. In contrast, stereotypes about male politicians proved to be similar to those about men in general. Women politicians were more likely than their male counterparts to be defined by their deficits rather than their strengths. They were said to lack the strengths associated with being a woman (e.g. sensitivity and compassion) as well as the leadership, competence and other traits connected with male politicians (Schneider - Bos 2014: 260-261). 
It should be stressed that the different perceptions of men and women in politics may not have a negative effect on their popularity or the effectiveness of their election campaigns (Aalberg - Jenssen 2007: 17). By taking a stand on different policies, women may introduce new issues into the political sphere and so attract new or less mobilised groups of voters. The idea here is that female politicians can open up new aspects of party competition through their emphasis on new issues. Similarly, these politicians may introduce new kinds of personal strengths into politics, including communication skills, compassion and the ability to persuade important segments of the electorate. Against this, election campaigns may serve to ignite stereotypes. As more political advertisements are broadcast during a campaign, there is greater likelihood that voters will watch them and this will affect their decisions. Exposure to stereotype-laden spots about women lowers the probability of voting for a female incumbent (Bauer 2015).

A study by Okimoto and Brescoll (2010) showed that when female candidates openly admitted that they wanted to gain power during election campaigns, their chances of success decreased. Negative campaigns were more likely to trigger a backlash if they were led by women (Krupnikov - Bauer 2014).

Politicians who show emotion may also be assessed differently depending on their gender (Lewis 2000). Women are perceived more positively when they express no emotions than when they display sadness or anger. In contrast, men are seen more positively when they show anger or no emotions than when they express sadness. A study by Tiedens (2001) found that whenever Bill Clinton expressed anger, his prospects improved.

\section{The research problem}

As we have seen, people expect politicians to have traits and dispositions that are incompatible with the socially and culturally accepted female role. Women are seen as empathetic, conciliatory, friendly and mild, while the political world is perceived as ruthless and combative. The current study aims to compare the importance of two factors: the traits attributed to women and those ascribed to politicians. A study by Gawor (2006) found that perceptions of women politicians focused on their appearance, traits, social skills, motivations for entering politics and typical activities. This list suggests that women politicians are seen in terms of categories typically applied to women and those typically applied to men, which shows the interaction of these two factors.

This article seeks to establish whether women in Polish politics are perceived through the prism of gender stereotypes. To this end, we compare the descriptive categories that organise perceptions of male and female politicians.

Three additional variables have been added to our survey: the respondent's gender, the extent of their interest in politics and their ideological self- 
-identification. All these factors may have a significant effect on how women politicians are perceived. Interest in politics is the variable most frequently associated with subjective political knowledge. The greater an individual's interest in politics, the more likely it is that they can assess and interpret political phenomena and processes (Jakubowska 1999). Moreover, interest in politics translates into greater exposure to political stimuli, which, in turn, increases political participation (Skarżyńska 2002). The second variable is the respondent's ideological self-identification, as seen from their location on a spectrum extending from left to right. We assumed that individuals closer to the extreme right would uphold traditional values and be more likely to perceive women in terms of stereotypical roles connected with the family and household. These respondents would, thus, find it harder to see a role for women in politics.

In order to satisfy our research objectives, we needed to compare perceptions of men and, thus, ensure a deeper analysis of the research problem. Our approach aimed to highlight not only the importance and interaction of different associations with "female politician" but also their relationship to comparable associations with "male politician." Through the research process, we tried to find answers to the following questions:

1. What descriptive categories underlie perceptions of female politicians?

2. What descriptive categories underlie perceptions of male politicians?

3. Does a voter's gender modify their perceptions of men and women in the political space?

4. Does a voter's interest in politics modify their perceptions of men and women in the political space?

5. Does a voter's ideological self-identification modify their perceptions of women and men in the political space?

The first two questions were exploratory. The third one aimed to test our assumption that there is a relationship between a person's gender and their perceptions of women in politics. Our working hypothesis was that based on gender solidarity, women voters would perceive women politicians more positively while male voters would take a more favourable view of male politicians.

Turning to the fourth question, we presumed that we would find a significant correlation between the level of a voter's interest in politics and their perceptions of female and male politicians. In particular, we predicted that greater interest in politics would translate into a higher level of political knowledge, and that in line with McDermott's (1998) findings, this would substantially reduce reliance on stereotypes. Knowledge can minimise simplistic reasoning and limit the use of cognitive heuristics when making evaluations.

The last question explored the relationship between leftist and rightist self-identifications and perceptions of women and men in politics. We assumed that because of their attachment to conservative values including the traditional 
division of gender roles, right-wing voters would rely on stereotypes to a greater degree. As such, they would perceive men in terms reserved for descriptions of political life while their perceptions of women would reflect stereotypical female traits.

\section{Methodology}

The first stage of our research was a pilot study involving 100 participants. The sample was diverse in terms of age (18-24: 15\%; 25-34: 16\%; 35-44: 18\%; 45-54: 17\%; 55-64: 18\%; over 65: 16\%), gender (women: 52\%; men: $48 \%$ ) and place of residence (town: $56 \%$; village: $44 \%$ ). The respondents were asked to answer two open-ended questions: "What do you associate female politicians with?" and "What do you associate male politicians with?" There was no limit on the number of qualities that respondents could mention. They were asked first about female politicians and then separately about male politicians so as to minimise the risk of being guided by their initial associations with male politicians. Otherwise, the qualities listed might have referred to men to a greater degree. We then compiled a list of the qualities used most frequently to characterise each of the genders in the pilot study. "Overall 146 qualities were selected for both genders, and these were assessed by qualified judges". The latter were 12 experts consisting of three psychologists, four political scientists, three sociologists and two cultural critics. Based on their assessment, we selected 50 characteristics for female politicians and 50 characteristics for male politicians to be included in the final assessment tool.

The actual study took place in late November and early December 2016. The respondents were students at the University of Silesia in Katowice who were enrolled in licentiate or master's degree courses in the following areas: political science, psychology, journalism and communications, political and public sector consultancy, domestic and international security and film and TV production. The group consisted of 276 women and 171 men - a total of 447 people.

The respondents first filled in a questionnaire in which they were asked to evaluate the degree to which women and men in politics displayed particular characteristics. The same inventory of characteristics that had been identified for each gender in the pilot study was applied to them again in this context. The respondents used a five-point scale extending from 1 ("not at all") to 5 ("a great deal"). Interest in politics was also measured on a five-point scale, with 1 denoting a complete lack of interest and 5 a very high level of interest. Ideological self-identifications took place on the left-right spectrum. For this purpose, respondents used a seven-point scale, selecting from the categories extreme left, left, centre-left, centre, centre-right, right and extreme right or else choosing the "I don't know" option. 


\section{Results}

In the first stage of the research, we verified the significance of the differences between the perceived characteristics of female and male politicians. The t-Student test for dependent samples showed that the characteristics used to describe female politicians were different from those applied to their male counterparts. As the table below shows, certain characteristics were attributed significantly more often to each gender.

\section{Table 1: Significant differences between the perceived characteristics of female and male politicians}

\begin{tabular}{|c|c|}
\hline Female politician & Male politician \\
\hline $\begin{array}{l}\text { ambitious }(t=5.109 ; d f=446 ; p=.001) \\
\text { kind-hearted }(t=15.920 ; d f=446 ; p=.001) \\
\text { well-organised }(t=6.247 ; d f=446 ; p=.001) \\
\text { elegant }(t=11.475 ; d f=446 ; p=.001) \\
\text { empathetic }(t=13.360 ; d f=446 ; p=.001) \\
\text { trustworthy }(t=9.472 ; d f=446 ; p=.001) \\
\text { intelligent }(t=2.206 ; d f=446 ; p=.001) \\
\text { competent }(t=3.133 ; d f=446 ; p=.002) \\
\text { forms relationships easily }(t=3.616 ; d f=446 ; \\
\qquad p=.001) \\
\text { naive }(t=6.045 ; d f=446 ; p=.001) \\
\text { responsible }(t=2.201 ; d f=446 ; p=.028) \\
\text { caring }(t=9.392 ; d f=446 ; p=.001) \\
\text { hard-working }(t=9.298 ; d f=446 ; p=.001) \\
\text { a go-getter }(t=2.509 ; d f=446 ; p=.012) \\
\text { friendly }(t=11.400 ; d f=446 ; p=.001) \\
\text { reliable }(t=7.569 ; d f=446 ; p=.001) \\
\text { weak }(t=3.481 ; d f=446 ; p=.001) \\
\text { calm }(t=7.289 ; d f=446 ; p=.001) \\
\text { nice }(t=10.347 ; d f=446 ; p=.001) \\
\text { submissive }(t=6.393 ; d f=446 ; p=.001) \\
\text { fights for the rights of others }(t=10.138 ; d f=446 ; \\
\quad p=.001) \\
\text { socially engaged }(t=6.191 ; d f=446 ; p=.001) \text {. }\end{array}$ & $\begin{array}{l}\text { Supports nepotism }(t=8.385 ; d f=446 ; p=.001) \\
\text { ruthless }(t=5.633 ; d f=466 ; p=.001) \\
\text { works for the good of the party }(t=2.088 ; d f=446 ; \\
\quad p=.037) \\
\text { egotistical }(t=9.702 ; d f=446 ; p=.001) \\
\text { hypocritical }(t=6.415 ; d f=446 ; p=.001) \\
\text { careerist }(t=5.398 ; d f=446 ; p=.001) \\
\text { combative }(t=3.831 ; d f=446 ; p=.001) \\
\text { lazy }(t=7.360 ; d f=446 ; p=.001) \\
\text { manipulative }(t=10.303 ; d f=446 ; p=.001) \\
\text { strong }(t=3.080 ; d f=446 ; p=.002) \\
\text { competitive }(t=11.569 ; d f=446 ; p=.001) \\
\text { has high self-esteem }(t=3.302 ; d f=446 ; p=.001) \\
\text { resolute }(t=3.685 ; d f=446 ; p=.001)\end{array}$ \\
\hline
\end{tabular}

Other characteristics were not ascribed significantly differently based on the politician's gender. This was true of the following traits: devoid of ideals; controllable; a good negotiator; media-savvy; copes with problems; independent; self-composed; courageous; enterprising; represents the community; reasonable; has a sense of humour; content with life and determined.

Female politicians were significantly more likely to be ascribed traits connected with caring for others and the ability to listen to their problems. In contrast, male politicians were associated considerably more often with features commonly linked to politics, for example, being ruthless or combative (Mouffe 2005). 
In the next stage, we verified the factors highlighted in perceptions of female and male politicians using a factorial analysis. Varimax rotation was performed to rotate the factors. Only items with a loading of $>0.3$ were counted for each factor. In the case of women, the final analysis included 26 statements that were divided across three factors, producing a total variance of $41.74 \%$. For men, 29 statements were chosen and these were also divided across three factors. The result was a total variance of $40.68 \%$.

Table 2: Factors and key traits in the perception of female and male politicians

\begin{tabular}{|c|c|c|}
\hline \multicolumn{3}{|c|}{ Female politician } \\
\hline $\begin{array}{l}\text { (F1) political ability and self- } \\
\text { composure }\end{array}$ & $\begin{array}{l}\text { (F2) public appeal and sense of } \\
\text { civic duty }\end{array}$ & (F3) competitiveness \\
\hline $\begin{array}{l}\text { competent } \\
\text { intelligent } \\
\text { copes with problems } \\
\text { resolute } \\
\text { self-composed } \\
\text { enterprising } \\
\text { strong } \\
\text { a good negotiator } \\
\text { independent }\end{array}$ & $\begin{array}{l}\text { friendly } \\
\text { kind-hearted } \\
\text { socially engaged } \\
\text { empathetic } \\
\text { fights for the rights of others } \\
\text { represents the community } \\
\text { forms relationships easily } \\
\text { nice } \\
\text { has a sense of humour } \\
\text { calm } \\
\text { elegant } \\
\text { caring }\end{array}$ & $\begin{array}{l}\text { has high self-esteem } \\
\text { competitive } \\
\text { ruthless } \\
\text { careerist } \\
\text { manipulative }\end{array}$ \\
\hline
\end{tabular}

Total variance $=41.74 \%$

\begin{tabular}{|c|c|c|}
\hline \multicolumn{3}{|c|}{ Male politician } \\
\hline (F1) political ability and diligence & $\begin{array}{l}\text { (F2) public appeal and go-getter } \\
\text { attitude }\end{array}$ & (F3) ruthless competitiveness \\
\hline $\begin{array}{l}\text { reliable } \\
\text { hard-working } \\
\text { competent } \\
\text { copes with problems } \\
\text { resolute } \\
\text { enterprising } \\
\text { a good negotiator } \\
\text { intelligent } \\
\text { well-organised } \\
\text { determined } \\
\text { independent } \\
\text { strong }\end{array}$ & $\begin{array}{l}\text { friendly } \\
\text { caring } \\
\text { nice } \\
\text { kind-hearted } \\
\text { empathetic } \\
\text { has a sense of humour } \\
\text { calm } \\
\text { a go-getter }\end{array}$ & $\begin{array}{l}\text { supports nepotism } \\
\text { manipulative } \\
\text { egotistical } \\
\text { combative } \\
\text { careerist } \\
\text { competitive } \\
\text { hypocritical } \\
\text { ruthless } \\
\text { has high self-esteem }\end{array}$ \\
\hline
\end{tabular}

Total variance $=40.63 \%$

Source: Authors' study 
The factor most emphasised in perceptions of female and male politicians was their possession of the qualities needed to be a politician, or what can be summed up as political ability. Individuals with these qualities were said to be resolute, enterprising, independent, strong leaders, able to cope with problems, intelligent, competent and highly skilled at negotiation. Interestingly, this category varied slightly depending on whether it was applied to women or men. For women, self-composure was added to the list. In contrast, for men, this category was seen as part of a broader set of qualities reflecting diligence and reliability, i.e. being well-organised, reliable, a hard worker and determined. For women, this factor was, thus, called political ability and self-composure, while for men, it was labelled political ability and diligence. This may also explain why this factor featured in perceptions of male and female politicians to a similar degree: for men, the variance was $19.69 \%$ and for women it was $18.95 \%$.

The second factor related to the characteristics that reflect a politician's public appeal. These are "soft" skills that support relationship-building and are valuable in social interactions. Characteristics associated with this factor included being friendly, kind-hearted, nice, caring, empathetic, calm and having a good sense of humour. In the case of women, this factor also encompassed some extra characteristics that showed the politician's commitment to working for the public benefit. These traits included being socially engaged, fighting for the rights of others, representing the community and forming relationships easily. Elegance was another characteristic factored in for women. For men, on the other hand, this category was extended to include having a go-getter attitude. Based on all these considerations, this factor was described as public appeal and a sense of civic duty in the case of women, while for men, it was public appeal and a go-getter attitude. There was significantly more variance in perceptions of this factor among female politicians (14.94\%) compared to their male counterparts $(10.70 \%)$.

The third factor concerned the politician's self-orientation. This was associated with characteristics such as having high self-esteem and being competitive, ruthless, careerist, manipulative and media-savvy. Interestingly, our study showed that this category was significantly broader in the case of men. Male politicians were perceived as approving of nepotism and being egotistical, combative and hypocritical. Taking all this into account, this factor was described as competitiveness in the case of women and ruthless competitiveness when it came to men. There was also significantly more variance in the perception of this factor in male politicians: the result was $10.23 \%$ for men compared to $7.85 \%$ for women. 
The third stage of the study considered differences in the perception of female and male politicians among groups with different levels of interest in politics and different ideological self-identifications. In order to verify these relationships, we performed t-Student testing along with a one-way analysis of variance (ANOVA) with post-hoc Tukey HSD.

Table 3: Factors in the perception of female and male politicians; differences and mean results for all-female versus all-male respondent groups

\begin{tabular}{|c|c|c|c|c|c|c|c|c|}
\hline Factor & $\begin{array}{l}\text { Gender } \\
\text { of group }\end{array}$ & $\mathbf{N}$ & Mean & $\begin{array}{l}\text { Standard } \\
\text { deviation }\end{array}$ & $\begin{array}{c}\text { Standard } \\
\text { error of mean }\end{array}$ & $\mathbf{t}$ & df & p \\
\hline \multirow{2}{*}{$\begin{array}{l}\text { Political ability } \\
\text { and self- } \\
\text { composure }\end{array}$} & Women & 276 & 3.7512 & .71017 & .04275 & \multirow{2}{*}{5.707} & \multirow{2}{*}{445} & \multirow{2}{*}{0.001} \\
\hline & Men & 171 & 3.3372 & .79895 & .06110 & & & \\
\hline \multirow{2}{*}{$\begin{array}{l}\text { Public appeal } \\
\text { and sense of } \\
\text { civic duty }\end{array}$} & Women & 276 & 3.7472 & 69391 & .04177 & \multirow{2}{*}{2.413} & \multirow{2}{*}{445} & \multirow{2}{*}{0.016} \\
\hline & Men & 171 & 3.5870 & .66296 & .05070 & & & \\
\hline \multirow{2}{*}{ Competitiveness } & Women & 276 & 3.4141 & .58536 & .03523 & \multirow{2}{*}{1.860} & \multirow{2}{*}{445} & \multirow{2}{*}{ n.s. } \\
\hline & Men & 171 & 3.3616 & .54815 & .04192 & & & \\
\hline \multirow{2}{*}{$\begin{array}{l}\text { Political ability } \\
\text { and diligence }\end{array}$} & Women & 276 & 3.5484 & .71748 & .04319 & \multirow{2}{*}{-2.921} & \multirow{2}{*}{445} & \multirow{2}{*}{0.004} \\
\hline & Men & 171 & 3.7540 & .73168 & .05595 & & & \\
\hline \multirow{2}{*}{$\begin{array}{l}\text { Public appeal } \\
\text { and go-getter } \\
\text { attitude }\end{array}$} & Women & 276 & 2.9199 & .64530 & .03884 & \multirow{2}{*}{-3.664} & \multirow{2}{*}{445} & \multirow{2}{*}{0.001} \\
\hline & Men & 171 & 3.1475 & .62702 & .04795 & & & \\
\hline \multirow{2}{*}{ Ruthlessness } & Women & 276 & 3.3388 & .72872 & .04386 & \multirow{2}{*}{1.780} & \multirow{2}{*}{445} & \multirow{2}{*}{ n.s. } \\
\hline & Men & 171 & 3.2150 & 69049 & .05280 & & & \\
\hline
\end{tabular}

The gender of respondents significantly affected the perception of female and male politicians in the case of all but the third of the factors identified. The outcomes of this study showed gender solidarity: women were significantly more likely to attribute political ability and self-composure as well as public appeal and a sense of civic duty to female politicians. Men, in turn, were more likely to ascribe the equivalent factors to male politicians. 
Table 4: Variance* and post-hoc Tukey HSD test for each factor in the perception of female and male politicians; results for groups with different preferences on the left-right ideological spectrum

\begin{tabular}{|c|c|c|c|c|c|c|c|}
\hline \multirow{2}{*}{ Factor } & \multicolumn{4}{|c|}{ Medium } & \multicolumn{2}{c|}{ ANOVA (df=446) } & \multirow{2}{*}{ Tukey's HSD } \\
\cline { 2 - 7 } & $\begin{array}{c}\text { Left } \\
(\mathbf{N}=77)\end{array}$ & $\begin{array}{c}\text { Centre } \\
(\mathbf{N}=\mathbf{8 4})\end{array}$ & $\begin{array}{c}\text { Right } \\
(\mathbf{N}=\mathbf{1 6 0})\end{array}$ & $\begin{array}{c}\text { Don't } \\
\text { know }\end{array}$ & $\mathbf{F}$ & $\mathbf{p}$ & \\
\hline $\begin{array}{c}\text { Political ability and } \\
\text { self-composure }\end{array}$ & 3.6032 & 3.6561 & 3.4986 & 3.6640 & 1.350 & n.s. & - \\
\hline $\begin{array}{c}\text { Public appeal and } \\
\text { sense of civic duty }\end{array}$ & 3.5920 & 3.7183 & 3.6737 & 3.7373 & 0.795 & n.s. & - \\
\hline $\begin{array}{c}\text { Competitiveness } \\
\text { Political ability and } \\
\text { diligence }\end{array}$ & 3.3358 & 3.3776 & 3.3679 & 3.3923 & 0.159 & n.s. & - \\
\hline $\begin{array}{c}\text { Public appeal and } \\
\text { go-getter attitude }\end{array}$ & 2.8485 & 3.0437 & 3.1056 & 2.9541 & 3.193 & 0.023 & L/R p=0.021 \\
\hline Ruthlessness & 3.4156 & 3.2344 & 3.2245 & 3.3386 & 1.604 & n.s. & - \\
\hline
\end{tabular}

* The Levene's test results indicate that the variance for all factors was homogenous. The results were as follows: $F(3.443)=1.584, p=$ n.s.; $F(3.443)=1.483, p=$ n.s.; $F(3.443)=1.778, p=$ n.s.; $F(3.443)=1.394$, $p=$ n.s.; $F(3.443)=1.705, p=n . s . ; F(3.443)=0.407, p=$ n.s.

The results of our study showed no significant differences among groups with different ideological (left-right) preferences when it came to their perception of any factor in female politicians or the third factor in men. These groups did, however, have different perceptions of the political ability and diligence and the public appeal and go-getter attitude of male politicians. The post-hoc test showed that right-wing individuals were significantly more likely to see male politicians as politically capable and diligent than either left-wing respondents or those with no specified political orientation. Right-wing people also credited male politicians with public appeal and a go-getter attitude considerably more often their left-wing counterparts did. 
Table 5: Variance and post-hoc Tukey HSD test for each factor in the perception of female and male politicians; results for groups with different levels of interest in politics

\begin{tabular}{|c|c|c|c|c|c|c|}
\hline \multirow[b]{2}{*}{ Factor } & \multicolumn{3}{|c|}{ Medium } & \multicolumn{2}{|c|}{ ANOVA $(\mathrm{df}=446)$} & \multirow[b]{2}{*}{ Tukey's HSD } \\
\hline & $\begin{array}{c}\text { "I'm not } \\
\text { interested in } \\
\text { politics" (NI) } \\
(\mathrm{N}=116)\end{array}$ & $\begin{array}{l}\text { "I'm a little } \\
\text { interested in } \\
\text { politics" (LI) } \\
(\mathrm{N}=174)\end{array}$ & $\begin{array}{c}\text { "I'm } \\
\text { interested in } \\
\text { politics" }(\mathrm{I}) \\
(\mathrm{N}=157)\end{array}$ & $\mathbf{F}$ & $\mathbf{p}$ & \\
\hline $\begin{array}{l}\text { Political ability and } \\
\text { self-composure }\end{array}$ & 3.7040 & 3.6795 & 3.4289 & 6.733 & 0.001 & $\begin{array}{r}\mathrm{I} / \mathrm{NI} p=0.010 \\
\mathrm{LI} / \mathrm{p}=0.013\end{array}$ \\
\hline $\begin{array}{l}\text { Public appeal and } \\
\text { sense of civic duty }\end{array}$ & 3.7198 & 3.7388 & 3.6144 & 3.496 & n.s. & - \\
\hline Competitiveness & 3.4224 & 3.3394 & 3.3758 & 2.033 & n.s. & - \\
\hline $\begin{array}{l}\text { Political ability and } \\
\text { diligence }\end{array}$ & 3.4784 & 3.6537 & 3.7102 & 2.496 & 0.029 & $\mathrm{NI} / \mathrm{l} p=0.025$ \\
\hline $\begin{array}{l}\text { Public appeal and } \\
\text { go-getter attitude }\end{array}$ & 2.9339 & 3.0405 & 3.0255 & 0.730 & n.s. & - \\
\hline $\begin{array}{l}\text { Ruthless } \\
\text { competitiveness }\end{array}$ & 3.3924 & 3.1792 & 3.3361 & 2.746 & 0.032 & $\mathrm{NI} / \mathrm{LI} p=0.040$ \\
\hline
\end{tabular}

Source: Authors' study

Regarding groups with different levels of interest in politics, our results showed no differences when it came to the perception of two "female" factors (public appeal and a sense of civic duty and competitiveness) or one "male" factor (public appeal and a go-getter attitude). At the same time, people with an interest in politics associated women with political ability and self-composure significantly less often than those with little interest or no interest at all. People who were interested in politics also attributed political ability and diligence to men considerably more often. Those with no such interest were significantly more likely to see men as ruthlessly competitive than people who said they had little interest.

\section{Discussion}

Five questions were posed to respondents in the course of our research. The first two referred to the descriptive categories informing perceptions of female and male politicians. Our findings showed significant differences in the perception of women and men in the political sphere. First, female politicians were significantly more likely to be attributed traits connected with caring for others and being able to listen to their problems while male politicians were identified considerably more often with features commonly associated with politics such as ruthlessness and combativeness. This finding correlated with research which shows the association of female politicians with typically "female" issues (Sapiro 
1982; Matland 1994) and their perception in terms of stereotypically feminine qualities - e.g. compassion, expressiveness, honesty and greater interest in and proficiency at activities like caring for children and dealing with poverty, education and health care.

Our identification of the factors behind perceptions of male and female politicians also revealed some interesting differences. The first two factors for both genders focused on a similar root idea (political ability and public appeal). While in the first case, the degree of variance was similar for male and female politicians, there was slightly more variance in perceptions of women politicians' public appeal. This disproportion was likely due to the saturation of this category with stereotypically female attributes. In contrast, the third category (competitiveness, further specified as ruthless competition for men) produced more variance when it was applied to male politicians. Moreover, in the case of men, this factor took into account more characteristics. Its content came close to Machiavellianism, a philosophy introduced into social psychology by Richard Christie. This doctrine assigns four traits to leaders: a lack of emotion in interpersonal relations, which allows them to treat partners instrumentally; the abrogation of moral norms, which enables application of the principle "the ends justify the means"; the lack of any ideological agenda, which means they can focus strictly on pragmatic goals and the absence of clear psychopathy so they do not lose contact with reality (Pilch 2008: 231).

The third question referred to the difference that a respondent's gender makes to their perceptions of women and men in the political space. In line with our hypothesis, we found that there was evidence of gender solidarity. Women were significantly more likely to ascribe political ability and self-composure as well as public appeal and a sense of civic duty to female politicians. Men, in turn, more often characterised male politicians as having the equivalent qualities. In the case of the third factor (competitiveness or ruthless competitiveness), there were no statistically significant differences.

The fourth research question introduced the variable of the respondent's interest in politics. Here we found that our hypothesis that greater interest would reduce reliance on stereotypes was not confirmed. In contrast with McDermott's (1998) findings, our results showed that interest in politics did not significantly affect perceptions of female and male politicians as far as the factor public appeal and a sense of civic duty/public appeal and a go-getter attitude was concerned. This was also true of ruthless competitiveness in the case of male politicians. People who were interested in politics were significantly less likely to perceive women as having qualities connected with political ability and self-composure. Interestingly, the results for this category were different for male politicians. Those with more interest in politics associated men with characteristics linked to political ability and diligence more often. Our results may have been affected by the fact that the men in our sample declared a higher level of interest 
in politics ( $\mathrm{W}=2.92 \mathrm{M}=3.57 ; \mathrm{t}=-6.963 ; \mathrm{df}=343.875 ; \mathrm{p}=.001)$, which is typical in many world democracies (Atkeson - Rapoport 2003; Turska-Kawa 2011: 274).

The fifth question considered the impact of ideological self-identifications on the left-right spectrum on perceptions of female and male politicians. In this case, our hypothesis was partially confirmed: right-wing self-identifications did affect perceptions of men in politics. Our study showed that ideological identifications did not have a significant impact on perceptions of female politicians. In contrast, respondents identifying as right-wing more often perceived male politicians as politically capable and diligent and having strong public appeal and a go-getter attitude. The reasons for the situation may be twofold. First, it may reflect specific features of the current Polish political scene where no left-wing party has any seats in parliament. The outlook may be more positive among right-wing people who see their own political views being represented. At the same time, Polish politics remains male-dominated: despite her position, Prime Minister Beata Szydło is viewed as dependent on others in her party. For right-wing individuals, the image of male politicians tends to be filled with positive characteristics.

\section{Conclusions}

Our study is part of a larger trend of research that considers the influence of gender stereotypes on perceptions of female and male politicians. It provides a positive verification of this relationship. In particular, our research confirms the finding of earlier studies that women in politics are seen through the prism of certain stereotypical traits (Huddy - Terkildsen 1993; Burrell 1994; Kahn 1996). Furthermore, it supports Schneider and Bos's (2014) conclusion that stereotypes about female politicians largely conform with stereotypes about women in general. Women in the political realm are perceived as being more empathetic, trustworthy, consensus-oriented and interested in caring for others. These characteristics do not correspond with ideas about politics, which is widely perceived as a sphere of conflict and ruthless rivalry.

The sample group in our study consisted of social science students, and this calls for some additional comments about the interpretation of the findings. First, people with a higher level of education are likely to display less use of stereotypes in their political thinking; this is connected with their greater level of knowledge and political awareness (Falk - Kenski 2006). Second, since 2002, the right-wing identification of young people (aged 18-24) has been a key feature of the political scene. Interestingly, in the period when our research was carried out, there was a drop in the share of this young cohort who identified as right-wing (Głowacki 2017). In this regard, we may assume that young people's right-wing ideologies have complex determinants and these may not entail a conservative approach to socio-political issues, which is associated with reli- 
ance on stereotypes. Moreover, the period when participating students gained the right to vote coincided with the move to include women in Polish politics. These young people were, thus, naturally exposed to women holding important political offices, which may have made them less prone to stereotyping. We are aware that samples made up of students tend to be homogeneous not only in terms of age and education but also certain psychological characteristics: they display weak self-definitions, a high level of egocentricity and a strong need for peer approval (Sears 1986). By recruiting students of the social sciences and the humanities, i.e. disciplines involving daily professional contact with others, we tried to minimise the limitations associated with student samples. Students of these courses are constantly called on to improve their interpersonal relations and stay open-minded and empathetic. Furthermore, Kardes (1996) and Lucas (2003) observe that students make appropriate research subjects if the stress is on basic psychological processes. The perception process, which involves interpreting and attributing meaning to sensory experience definitely falls in this category. This conclusion is reinforced by the innate nature of psychological processes accompanying the stages of human development. Because of this internal coherence in student samples, they are also valuable for comparative studies carried out in different countries (Sears 1986; Druckman - Kam 2011).

The results of our analysis may be beset by two other kinds of limitation. The first is the overrepresentation of women in the study sample. Given the gender solidarity principle, this may have led to a slightly more positive perception of women than would have been the case with a more diverse sample. The other factor is the possibility of a social desirability bias, i.e. an inclination among respondents to present themselves in the best possible light by giving socially desirable responses (Fisher 1993; Grimm 2010). Such a bias can affect the validity of survey results, especially when questions concern socially sensitive issues. Our study was designed to limit the influence of this factor as much as possible: questions were constructed in a neutral way, and the survey was anonymous and performed in large respondent groups.

In the context of this broader discussion, it is worth considering the implications of our findings not only for political judgements and attitudes but, above all, for voters' decisions in elections. One interesting take on the influence of stereotypes on voters is presented by Sanbonmatsu (2002), who introduces the term "baseline gender preference." Her findings suggest that many people give primacy to one of the genders, and this inclination is formed by gender stereotypes. At the same time, many authors have speculated about whether there are certain situations where stereotypes are more readily activated and where contextual factors play a greater role. The question is important because much of the work establishing the major role of gender stereotypes has involved experiments or hypothetical situations (see, e.g., Adams 1975; Rosenwasser Dean 1989; Brown et al. 1993; Rosenthal 1995; Fox - Smith 1998; Sanbonmatsu 
2002; King - Matland 2003; Lawless 2004; Fridkin - Kenney 2009). More work is needed to highlight factors that can limit the activation of stereotypes in real-life situations.

In this respect, it must first be stressed that gender stereotypes change over time. Until the 1980s, women politicians were a kind of curiosity in the public domain and the issue of female representation was simply ignored (Mueller 1988; Listhaug et al. 1995). Recent studies show, however, that the public perceives women to be better performers in several areas traditionally associated with male politicians, including political leadership. The respondents in one study believed that women and men were equally destined to be good political leaders (Pew Research Center 2008).

Secondly, the influence of the party context on political decisions is also worth examining. Many studies emphasise the role of environmental factors which can neutralise the impact of gender in political elections (Huddy et al. 2002; Philpot - Walton 2007; Dolan 2010). This dominance of party cues as an information source makes all the more sense in an age of increasing party polarisation in politics as a whole (Bartels 2000; Fiorina et al. 2006; Layman et al. 2006).

Thirdly, taking into account that stereotypes traditionally fill "information gaps," a politician's image can be understood as a composite of stereotypes and reliable knowledge among voters. It may be hypothesised that voters with less knowledge resort more often resort to stereotypes. At the same time, one interesting study by Koch (2002) reached the opposite conclusion, noting that people with the highest level of knowledge relied on stereotypes significantly more often.

Finally, we may speculate that the greater presence of women in politics will help neutralise stereotypical notions about women. Research shows that the involvement of more women leaders contributes to greater voter support for female politicians in the following election as well as the greater desire of such leaders to participate in politics (Beaman et al. 2009; Bhavnani 2009; Ferreira Gyourko 2009). Furthermore, knowing about women politicians - and perhaps even having personal contact with them during electoral campaigns - makes voters see more and more non-stereotypical qualities in candidates, which, in turn, modifies initial perceptions.

Our study essentially confirms a thesis described in the literature and proven by other research: female politicians in Poland are perceived through the prism of gender stereotypes, which may be one of the reasons for the low proportion of women in parliament compared to the figure in Western European countries. This situation will not be changed by the introduction of $35 \%$ female quotas on candidate lists under the Electoral Code. This is clear from the lack of public support for equal opportunity measures for women in politics (Marmola Olszanecka 2012) and from the fact that most women leave politics because they cannot win seats despite the quota system (Flis 2012). In this context, there is 
a need for further exploration of the influence of institutional factors (e.g. the electoral system, the number of female representatives) and the political culture on gender stereotypes in politics. Including these factors in the analysis would definitely make clearer how permanent they are.

\section{References}

Aalberg, Toril - Jenssen, Anders T. (2007): Gender Stereotyping of Political Candidates: An Experimental Study of Political Communication. Nordicom Review 28(1): 17-32.

Adams, William (1975): Candidate Characteristics, Office of Election, and Voter Responses. Experimental Study of Politics 4: 76-88.

Alexander, Deborah - Andersen, Kristi (1993): Gender as a Factor in the Attribution of Leadership Traits. Political Research Quarterly 46(3): 527-545.

Atkeson, Lonna R. - Rapoport, Ronald B. (2003): The more things change the more they stay the same: examining gender differences in political attitude expression 1952-2000. Public Opinion Quarterly 67(4): 495-521.

Bakan, David (1966): The Duality of Human Existence: An Essay on Psychology and Religion. Chicago, IL: Rand McNally.

Bartels, Larry M. (2000): Partisanship and Voting Behavior, 1952-1996. American Journal of Political Science 44(1): 35-50.

Bauer, Nichole M. (2013): Rethinking stereotype reliance: Understanding the connection between female candidates and gender stereotypes. Politics and the life sciences 32(1): 22-42.

Bauer, Nichole M. (2015): Emotional, Sensitive, and Unfit for Office? Gender Stereotype Activation and Support Female Candidates. Political Psychology 36(6): 691-708.

Beaman, Lori, - Chattopadhyay, Raghabendra - Duflo, Esther - Pande, Rohini - Topalova, Petia (2009): Powerful Women: Does Exposure Reduce Bias? Quarterly Journal of Economics 124(4): 1497-1540.

Bhavnani, Rikhil R. (2009): Do Electoral Quotas Work after They Are Withdrawn? Evidence from a Natural Experiment in India. American Political Science Review 103(1): 23-35.

Brannon, Linda (2017): Gender: Psychological Perspectives. 7th ed., New York, NY: Routledge.

Brown, Clyde - Heighberger, Neil - Shocket, Peter (1993): Gender-Based Differences in Perceptions of Male and Female City Council Candidates. Women and Politics 13: 1-17.

Burrell, Barbara C. (1994): A Woman's Place Is in the House: Campaigning for Congress in the Feminist Era. Ann Arbor, Ml: University of Michigan Press.

Deaux, Kay - Lewis, Laurie L. (1984): Structure of gender stereotypes: Interrelationships among components and gender labels. Journal of Personality and Social Psychology 46(5): 991-1004.

Devroe, Robin - Wauters, Bram (2017): Political gender stereotypes in Flanders (Belgium): Competent men versus leftist women? Paper prepared for the European Consortium for Political Research general conference, 6-10 September 2017, Oslo, Norway. 
Dolan, Kathleen (2004): The Impact of Candidate Sex on Evaluations of Candidates for the U.S. House of Representatives. Social Science Quarterly 85(1): 206-217.

Dolan, Kathleen (2010): The Impact of Gender Stereotyped Evaluations on Support for Women Candidates. Political Behavior 32(1): 69-88.

Dolan, Kathleen (2014): Gender Stereotypes, Candidate Evaluations, and Voting for Women Candidates: What Really Matters? Political Research Quarterly 67(1): 96-107.

Druckman, James N. - Kam, Cindy D. (2011): Students as Experimental Participants: A Defense of the 'Narrow Data Base', in Druckman, James N. - Green, Donald P. - Kuklinski, James H. Lupia, Arthur, eds., Cambridge Handbook of Experimental Political Science, 1-57, New York, NY: Cambridge University Press.

Eagly, Alice H. (1987): Sex Differences in Social Behavior: A Social-Role Interpretation. Hillsdale, NJ: Erlbaum.

Falk, Erika - Kenski, Kate (2006): Issue Saliency and Gender Stereotypes: Support for Women as Presidents in Times of War and Terrorism. Social Science Quarterly 87(1): 1-18.

Ferreira, Fernando - Gyourko, Joseph (2009): Do Political Parties Matter? Evidence from U.S. Cities-super. The Quarterly Journal of Economics 124(1): 399-422.

Filipiak, Grażyna (2001): Kompetencja emocjonalna kobiet i mężczyzn a życie rodzinne. Roczniki Socjologii Rodziny XIII: 197-207.

Fiorina, Morris P. - Abrams, Samuel J. - Pope, Jeremy C. (2006): Culture War? The Myth of a Polarized America. 2nd. ed. New York, NY: Pearson Longman.

Fisher, Robert J. (1993): Social Desirability Bias and the Validity of Indirect Questioning. Journal of Consumer Research 20(2): 303-315.

Flis, Jarosław (2012): Skuteczność parytetu, in Turska-Kawa, Agnieszka - Wojtasik, Waldemar, eds., Wybory parlamentarne 2011, 79-102, Katowice: REMAR.

Fox, Richard L. - Smith, Eric R.A.N. (1998): The Role of Candidate Sex in Voter Decision-Making. Political Psychology 19(2): 405-419.

Fridkin, Kim L. - Kenney, Patrick J. (2009): The Role of Gender Stereotypes in U.S. Senate Campaigns. Politics \& Gender 5(3): 301-324.

Fuszara, Małgorzata (2010): Kobiety w polityce w okresie transformacji w Polsce, in Sochańska-Frąckowiak, Monika - Królikowska, Sabina, eds., Kobiety w polskiej transformacji 1989-2009: podsumowania, interpretacje, prognozy, 19-41, Toruń: Adam Marszałek.

Gawor, Agnieszka (2006): Stereotyp kobiety polityka a wybrane zmienne demograficzne i psychologiczne, in Bronowicka, Anna, ed., Wyzwania i zagrożenia demokracji w Polsce w obliczu wyborów 2005, 155-171, Opole: Wydawnictwo Uniwersytetu Opolskiego.

Głowacki, Antoni (2017): Czy młodzi Polacy są prawicowi?. Komunikat z badań nr 102. Warszawa: Centrum Badania Opinii Społecznej.

Goodman, Norman (1992): Wstęp do socjologii. Poznań: Wydawnictwo Zysk i S-ka.

Grimm, Pamela (2010): Social Desirability Bias. Wiley International Encyclopedia of Marketing. DOI: 10.1002/9781444316568.wiem02057. 
Hoffman, Curt - Hurst, Nancy (1990): Gender Stereotypes: Perception or Rationalization? Journal of Personality and Social Psychology 58(2): 197-208.

Huddy, Leonie - Terkildsen, Nayda (1993): Gender Stereotypes and the Perception of Male and Female Candidates. American Journal of Political Science 37(1): 119-147.

Huddy, Leonie - Feldman, Stanley - Capelos, Theresa - Provost, Colin (2002): The Consequences of Terrorism: Disentangling the Effects of Personal and National Threat. Political Psychology 23(3): 485-509.

Inter-Parliamentary Union (1995): Women in Parliaments, 1945-1995: A Word Statistical Survey. Geneva: Inter-Parliamentary Union.

Jakubowska, Urszula (1999): Preferencje polityczne. Psychologiczne teorie badania. Warszawa: Wydawnictwo Instytutu Psychologii PAN.

Jarymowicz, Maria (1976): Makiawelizm - osobowość ludzi nastawionych na manipulowanie innymi, in Reykowski, Janusz, ed., Osobowość a społeczne zachowanie się ludzi, 293-324, Warszawa: Książka i Wiedza.

Kahn, Kim F. (1993): Gender Differences in Campaign Messages: The Political Advertisements of Men and Women Candidates for the U.S. Senate. Political Research Quarterly 46(3): 481-502. Kahn, Kim F. (1996): The Political Consequences of Being a Woman: How Stereotypes Influence the Conduct and Consequences of Political Campaigns. New York, NY: Columbia University Press.

Kardes, Frank R. (1996): In Defense of Experimental Consumer Psychology. Journal of Consumer Psychology 5 (3): 279-296.

King, David C. - Matland, Richard E. (2003): Sex and the Grand Old Party: An Experimental Investigation of the Effect of Candidate Sex on Support for a Republican Candidate. American Politics Research 31(6): 595-612.

Koch, Jeffrey W. (1999): Candidate gender and assessments of senate candidates. Social Science Quarterly 80(1): 84-96.

Koch, Jeffrey W. (2002): Gender Stereotypes and Citizens' Impressions of House Candidates' Ideological Orientation. American Journal of Political Science 46(2): 453-462.

Krupnikov, Yanna - Bauer, Nichole M. (2014): The Relationship Between Campaign Negativity, Gender and Campaign Context. Political Behavior 36(1): 167-188.

Lambert, Alan J. - Wyer Jr/, Robert S. (1990): Stereotypes and social judgment: The effects of typicality and group heterogeneity. Journal of Personality and Social Psychology 59(4): 676-691.

Lau, Richard R. - Redlawsk, David P. (2001): Advantages and disadvantages of cognitive heuristics in political decision-making. American Journal of Political Science 45(4): 951-971.

Lawless, Jennifer L. (2004): Women, War, and Winning Elections: Gender Stereotyping in the post-September 11th Era. Political Research Quarterly 57(3): 479-490.

Layman, Geoffrey C. - Carsey, Thomas M. - Horowitz, Juliana M. (2006): Party Polarization in American Politics: Characteristics, Causes and Consequences. Annual Review of Political Science 9: 83-110.

Leeper, Mark S. (1991): The Impact of Prejudice on Female Candidates: An Experimental Look at Voter Inference. American Politics Quarterly 19(2): 248-261. 
Lewis, Kristi M. (2000): When Leaders Display Emotions: How Followers Respond to Negative Emotional Expressions of Male and Female Leaders. Journal of Organizational Behavior 21: 221-234.

Listhaug, Ola - Huseby, Beate - Matland, Richard E. (1995): Valgatferd blant kvinner og menn: 1957-1993, in Raaum, Nina C., ed., Kjønn og politick. Oslo, Norway: Tano Forlag.

Lucas, Jeffrey W. (2003): Theory-testing generalization, and the problem of external validity. Sociological Theory 21(3): 236-253.

Mandal, Eugenia (1995): Podmiotowe i interpersonalne konsekwencje stereotypów związanych z ptcią. Katowice: Wydawnictwo Uniwersytetu Śląskiego.

Marmola, Maciej - Olszanecka, Agata (2012): Partycypacja polityczna kobiet a wprowadzenie ustawowych kwot wyborczych. Preferencje Polityczne 3: 195-214.

Marody, Mirosława - Giza-Poleszczuk, Anna (2000): Być kobietą, być mężczyzną - czyli o przemianach tożsamości związanej z płcią we współczesnej Polsce, in Marody, Mirosława, ed., Między rynkiem a etatem. Społeczne negocjowanie polskiej rzeczywistości, 44-74, Warszawa: Scholar.

Marszałek, Lidia (2008): Kulturowe uwarunkowania roli kobiety we współczesnym społeczeństwie. Seminare. Poszukiwania naukowe 25: 267-279.

Matland, Richard E. (1994): Putting Scandinavian Equality to the Test: An Experimental Evaluation of the Gender Stereotyping of Political Candidates in a Sample of Norwegian Voters. British Journal of Political Science 24(2): 273-292.

McDermott, Monica L. (1998): Race and Gender Cues in Low-Information Elections. Political Research Quarterly 51(4): 895-918.

Mouffe, Chantal (2005): On the Political. London: Routledge.

Mueller, Carol M. (1988): The Politics of the Gender Gap. The Social Construction of Political Influence. Newbury Park, CA: Sage.

Norton, Noelle H. (1999): Uncovering the Dimensionality of Gender Voting in Congress. Legislative Studies Quarterly 24(1): 65-86.

Okimoto, Tyler G. - Brescoll, Victoria L. (2010): The Price of Power: Power Seeking and the Backlash Against Female Politicians. Personality and Social Psychology Bulletin 36(7): 923-936.

Paul, David - Smith, Jessi L. (2008): Subtle Sexism? Examining Vote Preferences When Women Run Against Men for the Presidency. Journal of Women, Politics \& Policy 29(4): 451-476.

Pew Research Center (2008): Men or Women: Who's the Better Leader? A Paradox in Public Attitudes: available at http://www.pewsocialtrends.org/2008/08/25/men-or-women-whos-the-better-leader/ (16 December 2016).

Philpot, Tasha S. - Walton, Hanes (2007): One of Our Own: Black Female Candidates and the Voters Who Support Them. American Journal of Political Science 51(1): 49-62.

Pilch, Irena (2008): Makiawelista wśród ludzi. Nowe badania. Psychologia spoteczna 3(8): 231-242.

Prentice, Deborah A. - Carranza, Erica (2002): What women and men should be, shouldn't be, are allowed to be, and don't have to be: The contents of prescriptive gender stereotypes. Psychology of Women Quarterly 26: 269-281. 
Rahn, Wendy M. (1993): The role of partisan stereotypes in information processing about political candidates. American Journal of Political Science 37(2): 472-496.

Reykowski, Janusz (2000): Psychologia polityczna, in Strelau, Jan, ed., Psychologia. Podręcznik akademicki. Gdańsk: GWP.

Rosenthal, Cindy S. (1995): The Role of Gender in Descriptive Representation. Political Research Quarterly 48(3): 599-611.

Rosenwasser, Shirley M. - Dean, Norma G. (1989): Gender Role and Political Office: Effects of Perceived Masculinity/Femininity of Candidate and Political Office. Psychology of Women Quarterly 13(1): 77-85.

Rosenwasser, Shirley M. - Seale, Jana (1988): Attitudes Toward a Hypothetical Male or Female Presidential Candidate: A Research Note. Political Psychology 9(4): 591-598.

Sanbonmatsu, Kira (2002): Gender Stereotypes and Vote Choice. American Journal of Political Science 46(1): 20-34.

Sapiro, Virginia (1982): If U.S. Senator Baker Were a Woman: An Experimental Study of Candidate Images. Political Psychology 3(1-2): 61-83.

Sapiro, Virginia (1983): The Political Integration of Women. Urbana, IL: University of Illinois Press.

Schneider, Monica C. - Bos, Angela L. (2014): Measuring Female Politician Stereotypes. Political Psychology 35(2): 245-266.

Sears, David O. (1986): College sophomores in the laboratory: Influences of a narrow data base on social psychology's view of human nature. Journal of Personality and Social Psychology 51(3): 515-530.

Siklova, Jirina (1993): Are women in Central and Eastern Europe conservative?, in Funk, Nanette Mueller, Magda, eds., Gender Politics and Post-Communism: Reflections from Eastern Europe and the Former Soviet Union, 74-83, New York, NY: Routledge.

Skarżyńska, Krystyna (2002): Podstawy psychologii politycznej. Poznań: Wydawnictwo Zysk i S-ka.

Thomas, Sue (1991): The Impact of Women on State Legislative Policies. Journal of Politics 53(4): 958-976.

Tiedens, Larissa Z. (2001): Anger and Advancement Versus Sadness and Subjugation: The Effect of Negative Emotion Expressions on Social Status Conferral. Journal of Personality and Social Psychology 80(1): 86-94.

Turska-Kawa, Agnieszka (2011): Political activation of young people. On the importance of the humanities for social practice, in Bokus, Barbara, ed., The Humanities Today and the Idea of Interdisciplinary Studies, 267-280, Warszawa: MATRIX Publishers.

Vasta, Ross M. - Haith, Marshall - Miller, Scott A. (1995): Psychologia dziecka. Warszawa: Wydawnictwa Szkolne i Pedagogiczne.

Verbrugge, Lois M. - Wingard, Deborah L. (1987): Sex Differences in Health and Mortality. Women and Health 12(2): 103-145. 
Agnieszka Turska-Kawa is an associate professor and deputy director of the Institute of Political Science and Journalism at the University of Silesia in Katowice/ Poland (Political Behaviour Research Unit). She holds degrees in political science and psychology and frequently combines this expertise in scientific research. In 2010, she completed her PhD at the University of Silesia, Katowice and Artes Liberales Academy in Warsaw and went on to receive her habilitation (a post-doctoral degree) in political science from the Faculty of Social Science at the University of Silesia. Today she leads the election research unit at the Polish Political Sciences Association and heads the IPSO ORDO academic foundation. Dr. hab. Turska-Kawa also works extensively with local governments on anti-corruption measures and is the University of Silesia's official representative at the European Consortium for Political Research. She is the editor-in-chief of the scientific journal Political Preferences (http: //www. journals.us.edu.pl/index.php/PP).E-mail: agnieszka.turska-kawa@us.edu.pl

Agata Olszanecka-Marmola is a research assistant and $\mathrm{PhD}$ candidate in political science at the Institute of Political Science and Journalism at the University of Silesia in Katowice, Poland. She is a member of the Polish Political Science Association and the European Consortium for Political Research. In 2013, she was awarded Master's degrees in political science and sociology. She is currently completing her $\mathrm{PhD}$ dissertation, which examines how TV political advertising affected political imagery in the 2015 Polish presidential elections. Her main research interests are political marketing, political communication (especially TV political advertising) and political psychology. E-mail: agata.olszanecka-marmola@us.edu.pl 